\title{
Estimation of Raindrop Size Distribution Parameters Using Lightning Data over West Sumatra
}

\author{
Faridah Salma $^{1}$, Marzuki Marzuki ${ }^{1}$, Hiroyuki Hashiguchi ${ }^{2}$, Fadli Nauval $^{3}$ \\ ${ }^{1}$ Department of Physics, Faculty of Mathematics and Natural Sciences, \\ Universitas Andalas, Padang 2516, West Sumatra, Indonesia \\ ${ }^{2}$ Research Institute for Sustainable Humanosphere (RISH), Kyoto University, Japan \\ ${ }^{3}$ Indonesian National Institute of Aeronautics and Space (LAPAN), Bandung, Indonesia
}

\begin{tabular}{|c|c|}
\hline Article Info & ABSTRACT \\
\hline Article History: & In situ observations of raindrop size distributions (DSDs) are still limited, \\
\hline Received: February 03, 2021 & $\begin{array}{l}\text { especially in the tropics. Therefore, this study develops an alternative method to } \\
\text { calculate DSD parameters by utilizing lightning data from the World-Wide }\end{array}$ \\
\hline Revised: February 10, 2021 & Lightning Location Network (WWLLN) observation. DSD data was obtained \\
\hline Accepted: February 11, 2021 & $\begin{array}{l}\text { from Parsivel's observations in the equatorial regions of Indonesia, i.e., } \\
\text { Kototabang }\left(100.32 \circ \mathrm{E}, 0.20^{\circ} \mathrm{S}, 865 \mathrm{~m} \text { above mean sea level/ASL). Padang }\right.\end{array}$ \\
\hline Keywords: & $\begin{array}{l}\left(100.46^{\circ} \mathrm{E}, 0.915^{\circ} \mathrm{S}, 200 \mathrm{~m} \mathrm{ASL}\right) \text {, and Sicincin }\left(100.30^{\circ} \mathrm{E}, 0.546^{\circ} \mathrm{S}, 134 \mathrm{~m}\right. \\
\mathrm{ASL}) \text {. A gamma distribution parameterized the DSD. Three analysis domains }\end{array}$ \\
\hline Raindrop size distribution & were examined, with a grid of $0.1^{\circ} \times 0.1^{\circ}, 0.5^{\circ} \times 0.5^{\circ}$, and $1^{\circ} \times 1^{\circ}$. We examined \\
\hline Lightning & the possibility to calculate the near-instantaneous DSD parameter, so three short \\
\hline$W W L L N$ & time intervals, namely, one, five and ten minutes, were used. The results showed \\
\hline Parsivel & that the number of lightning strokes does not adequately correlate with DSD \\
\hline West Sumatra & $\begin{array}{l}\text { parameters. This is observed in all time intervals and analysis domains. Thus, } \\
\text { the use of lightning data to calculate DSD parameters is not possible for short }\end{array}$ \\
\hline Corresponding Author: & $\begin{array}{l}\text { time interval of DSD (near instantaneous DSD). However, lightning data can be } \\
\text { used to estimate the average DSD parameters for an average time of more than }\end{array}$ \\
\hline Mar & one hour, as recommended by previous studies. \\
\hline
\end{tabular}

\section{INTRODUCTION}

Raindrop size distribution (DSD), the number of drops per unit size interval (usually equivolume spherical diameter) and per unit volume of space, has many applications (Jameson \& Konstinski, 2001). One of the applications of DSD is to define the physical processes in the formation of rain (Tokay \& Short, 1996). Raindrops reaching the ground have diverse characteristics depending on their movement during the creation and evolutionary process from their initial position to the ground. Furthermore, the application of DSD is necessarily beneficial in the design of remote sensing systems on meteorological radars and satellites (Coppens \& Haddad, 2000) as well as in the measurement of the level of soil erosion (Harikumar et al., 2009). In addition, the DSD is also used to convert weather radar data into rainfall (Uijlenhoet, 2010) and estimate rain attenuation (Owolawi, 2011).

Most of the researches related to DSD carried out in Indonesia was capitally in Kototabang. However, Marzuki et al. (2013a) then widely developed observations at several new sites: Biak, Manado, and Pontianak. It lasted, unfortunately, only in a year due to the high cost of maintaining the instrument. As a result, DSD observations in Indonesia are still very restricted. Therefore, other methods are 
increasingly required to obtain information about DSD in Indonesia, regardless of whether it is such direct observation or not.

The sensitivity of DSD towards storm characteristics has been undiscovered since several early DSD studies as conducted by Waldvoge (1974), where found changes in DSD when rain shifted from stratiform to convective type. Atlas et al. (1999) also showed the different forms of DSD between convective and stratiform precipitation. Furthermore, convection activity has a strong relationship with lightning (Avila et al., 2010). Therefore, if there is lightning data, the characteristics of the DSD will be able to get identified in an area and can be a solution towards the scarcity of DSD observations, especially in Indonesia. Saylor et al. (2005) and Lapp (2007) examined the relationship between lightning and DSD in the United States. They concluded that the data of lightning was able to be applied to obtain information related to DSD. However, the kinds of literature related to this topic were no longer available after Lapp (2007). In addition, the existing researches use a long time interval ( $\geq 1$ hour), so it is only possible to obtain the average DSD parameters. In many applications, near-instantaneous DSD is required.

This study aimed to look into the relationship between lightning and near-instantaneous DSD parameters in West Sumatra. We used DSD data observed by Particle Size Velocity (Parsivel), an Optical Laser-based Disdrometer that can measure rain particles (Loffler-Mang \& Joss, 2000), in Kototabang, Padang, and Sicincin (Marzuki et al., 2013a). In contrast to existing studies, the relationship between lightning and DSD parameters was calculated for a short time interval in this study. We examined the possibility to calculate the near-instantaneous DSD parameter, so three short time intervals, namely, one, five and ten minutes, were used.

\section{METHOD}

The DSD is obtained from Parsivel observations at Kototabang, Padang, and Sicincin, during 20172018 . Parsivel is an Optical Laser-based Disdrometer that can measure the size and velocity of droplets such as raindrops and snow. The observed parameters of Parsivel were stated in the unit of DSD, rain rate $(R)$, radar reflectivity $(Z)$, and Liquid Water Content $(L W C)$. The obtained data was stored on ASDO software. The size of raindrops was classified into 32 classes, furthermore, the number of the spectrum in the ASDO program would be 1024 classes $(32 \times 32)$. To further observe the characterization of DSD, DSD was modeled with gamma distribution as follows:

$$
N(D)=N_{T} \frac{\Lambda^{\mu+1} D^{\mu}}{\Gamma(\mu+1)} \exp (-\Lambda D)
$$

where $N(D)$ is DSD $\left(\mathrm{mm}^{-1} \mathrm{~m}^{-3}\right) . N_{T}$ is the intercept parameter $\left(\mathrm{m}^{-3}\right), m$ is the shape parameter and $\Lambda$ is the slope parameter $\left(\mathrm{mm}^{-1}\right)$. The calculation of gamma distribution parameters of DSD $\left(m, N_{\mathrm{T}}, \Lambda\right)$ used moment method. Moment method was initially developed based on the principle where the whole precipitation parameters are the function of DSD which generally can be declared as follows:

$$
M_{x}=\int_{0}^{\infty} N(D) D^{X} d D
$$

where $M_{\mathrm{x}}$ is the moment of DSD. Hence, equation (3) can be modified as follows (Kozu \& Nakamura, 1991):

$$
M_{x}=N_{T} \frac{\Gamma(\mu+x+1)}{\Lambda^{x} \Gamma(\mu+1)}
$$

According to equations (1) and (3), DSD parameters can be calculated by selecting the certain moments of DSD. In this study, moment $3^{\text {rd }}, 4^{\text {th }}$, and $6^{\text {th }}$ were applied (Kozu \& Nakamura, 1991; Marzuki et al., 2010; 2013a) as follows: 


$$
\begin{aligned}
& \mu=\frac{11 G-8+[G(G+8)]^{\frac{1}{2}}}{2(1-G)} \\
& G=\frac{M_{4}{ }^{3}}{M_{3}{ }^{2} M_{6}} \\
& N_{T}=\frac{\Lambda^{3} M_{3} \Gamma(\mu+1)}{\Gamma(\mu+4)} \\
& \Lambda=\frac{(\mu+4) M_{3}}{M_{4}}=\frac{(\mu+4)}{D_{m}}
\end{aligned}
$$

$D_{\mathrm{m}}\left(=M_{4} / M_{3}\right)$ is mass-weight average diameter, and $G$ is moment- $3^{\text {rd }}$ of the mass spectrum normalized by $D_{\mathrm{m}}{ }^{3}$.

The lightning data at each Parsivel location was obtained from observations of the World-Wide Lightning Location Network (WWLLN). WWLLN is a lightning observation network from the University of Washington that consists of lightning sensors at very low frequency (VLF) for 3-30 kHz (Albrecht, et al., 2015). Figure 1 shows the spatial distribution of the number of lightning occurrences in West Sumatra during 2017 - 2018. Number of lightning strokes from WWLLN is larger over land than over ocean and coastal areas, which is consistent with a previous study based on Tropical Rainfall Measuring Mission-Lightning Imaging Sensor (TRMM-LIS) data (Saufina, et al., 2018). Lightning data is calculated in three grid sizes around the Parsivel location, namely, $0.1^{\circ} \times 0.1^{\circ}, 0.5^{\circ} \times 0.5^{\circ}$ and $1^{\circ} \times$ $1^{\circ}$. This study examined the possibility to calculate the near-instantaneous DSD parameter, so three short time intervals, namely, one, five and ten minutes, were used. Changes in DSD parameters and rain rate against the time average were presented through a line graph. Subsequently, the results were illustrated in linear regression between number of lightning strokes and DSD parameters to represent the relationship of the number of lightning occurrences towards parameter of DSD and rain rate.

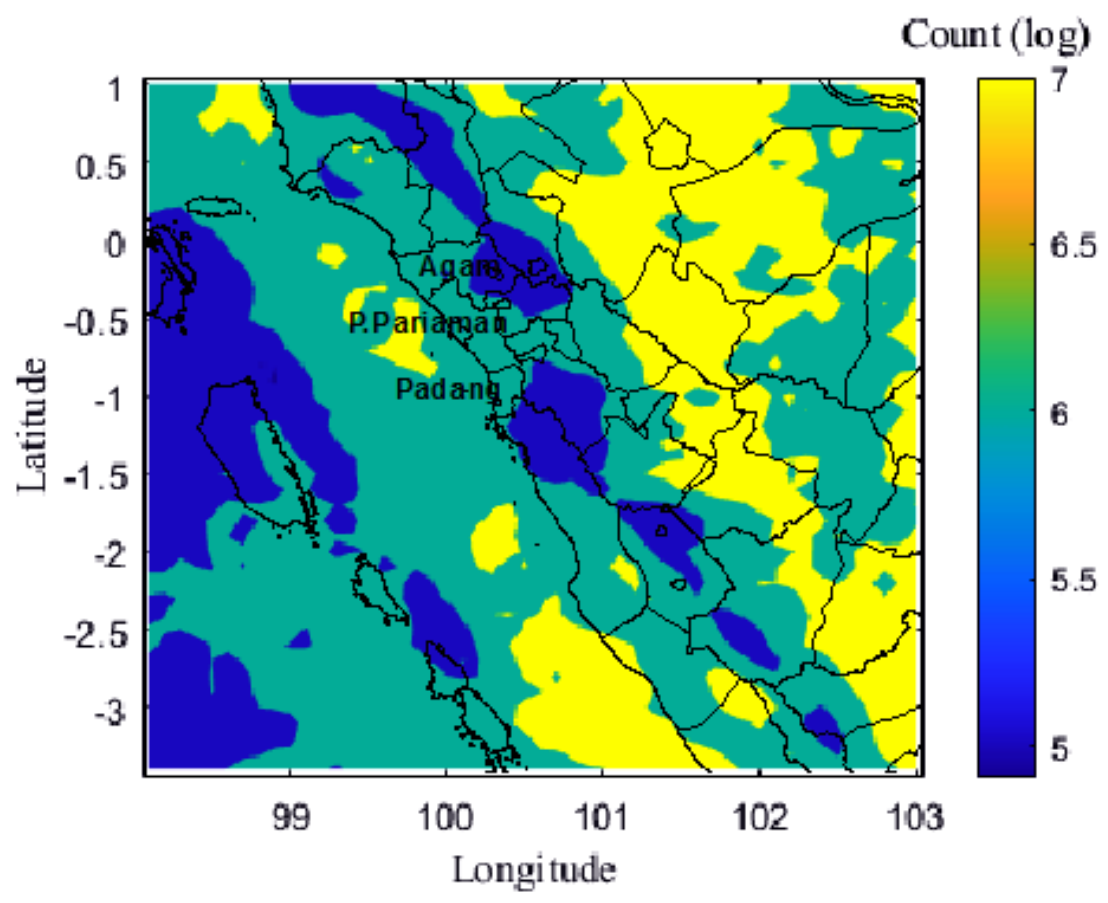

Figure 1 Spatial distribution of the number of lightning strokes in West Sumatra in $2017-2018$. The colorbar is given in logarithmic scale. 


\section{RESULTS AND DISCUSSION}

\subsection{Characteristics of Lightning for Each Parsivel location}

Figure 2 illustrates the number of monthly lightning occurrences in Kototabang, Padang, and Sicincin from 2017 to 2018. In a general trend, the flash of lightning more often occurred in 2018 than 2017. Concerning the study location, Sicincin had the most lightning number at 717. Meanwhile, those of Padang and Kototabang were at 445 and 205. Sicincin has the highest lightning density due to the topographical slope of this station which is greater than the other two stations, even though the location of Kototabang is higher. Lightning density is correlated with the terrain slope and not the altitude (Bourscheidt et al., 2009; Yusnaini et al., 2021). This can also be seen from the accumulation of rainfall, where Sicincin has the highest rainfall accumulation (Harjupa et al., 2021). The station's distance to the west coast of Sumatra may also affect the amount of lightning and rain (Marzuki et al., 2021).

Seasonal variation of lightning number is clearly observed. In general, the most thunderstorms occur in February, March and April. The second peak, although not as strong as the first peak, was observed in October, November and December. This pattern is consistent with peak rainfall (Marzuki et al., 2016), and lightning on mainland Sumatra based on observations from TRMM-LIS (Saufina, et al., 2018). However, in certain months Sumatra becomes wetter, due to changes in wind direction in relation to the Asian-Australian monsoon (Marzuki et al., 2013b). This also causes the West Sumatra region to have two peaks of rain throughout the year (Marzuki et al., 2016).

(a) Kototabang

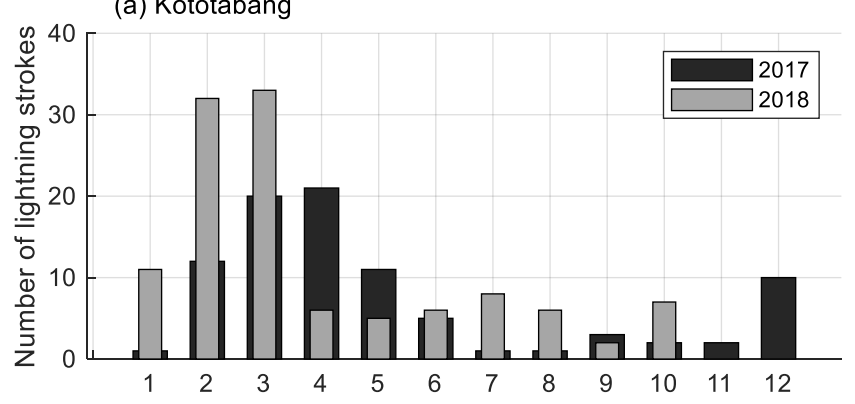

(b) Padang

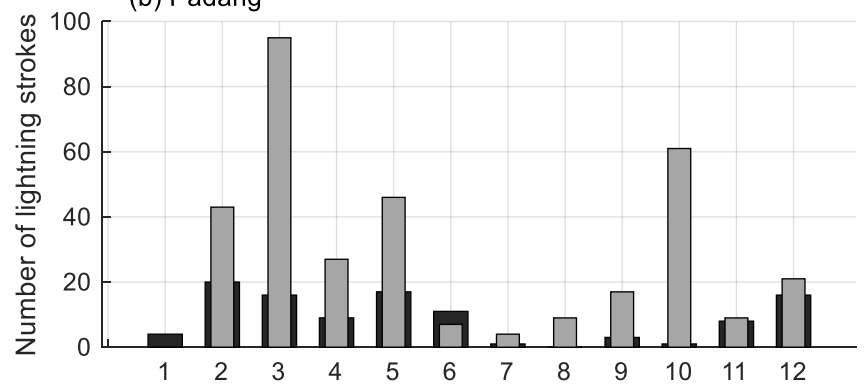

(c) Sicincin

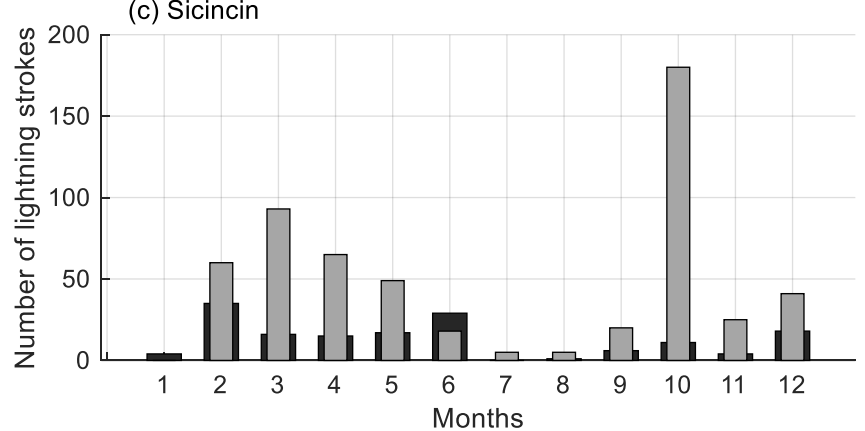

Figure 2 Number of lightning occurrences in Kototabang, Padang and Sicincin for each month during 20172018 , for the grid of $0.1^{\circ} \times 0.1^{\circ}$. 


\subsection{Relationship of Lightning Emergence with DSD Parameters}

Figures 3 presents relation between the number of lightning occurrence and parameter of DSD in Kototabang, for the grid of $0.1^{\circ} \times 0.1^{\circ}$. Besides DSD, the rain rate was displayed as well. The figure consists of three columns where the first column shows an average of one minute, of five minutes in the middle, and of ten minutes in the last. The result shows that there is no clue of indicating the strong relationship between rain rate $(R)$ and the number of lightning occurrences for an average of a minute where the value of determinant coefficient was zero. The number of lightnings for an average time of one minute is very small, so calculations are also carried out for an average time of 5 and 10 minutes. The correlation coefficient value increases but the value is still small with a maximum determinant coefficient of 0.08 for $\mu$ at an average time of 10 minutes (Table 1). Padang and Sicincin also showed a weak relationship between the number of lightning strokes and DSD parameters. For Padang, the correlation cannot be calculated due to the lack of simultaneous observation between Parsivel and WWLLN due to frequent blackouts.
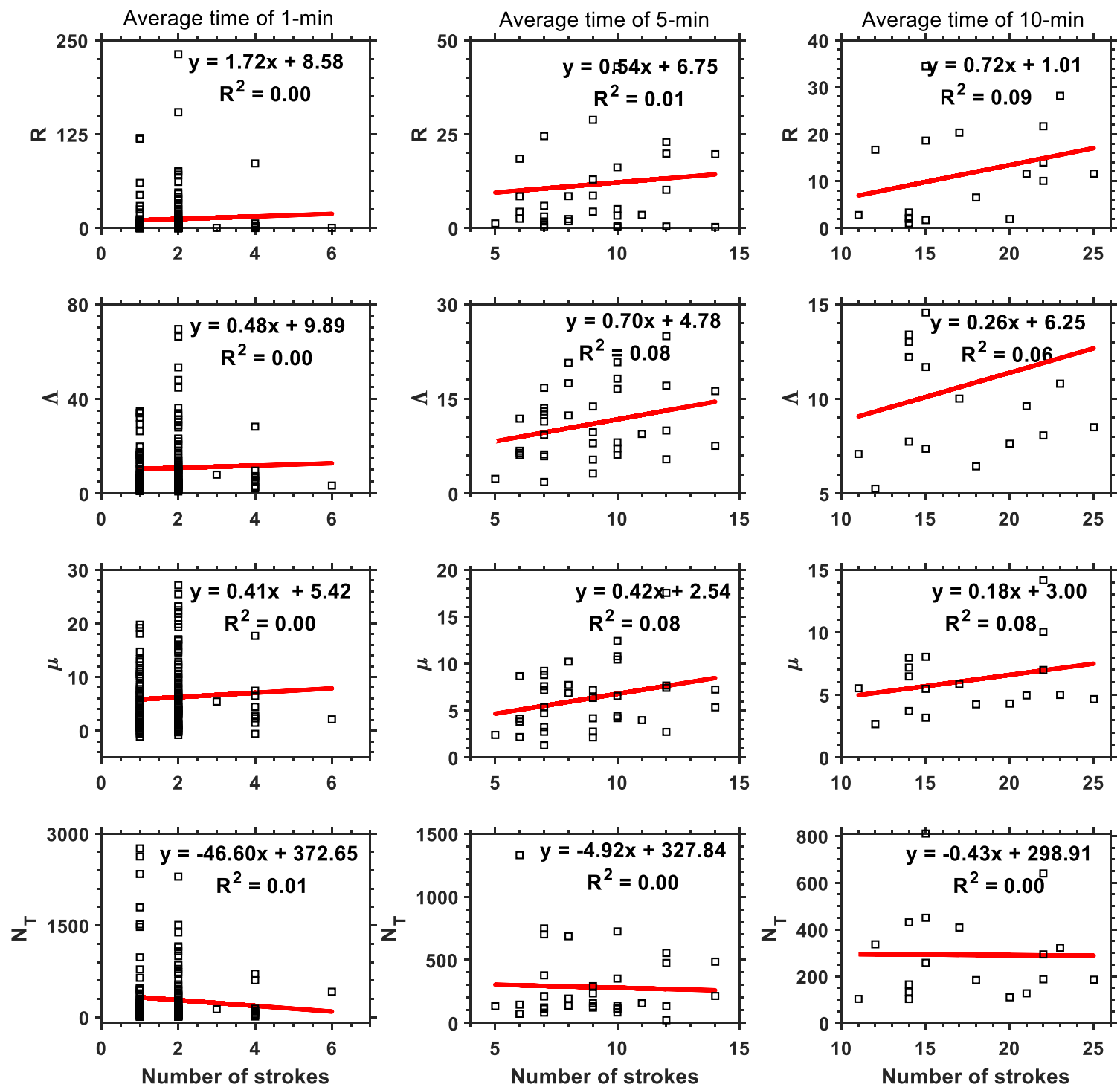

Figure 3 Relationship between the number of lightning strokes, rainfall rate, and DSD parameters in Kototabang for average time of one minute (left), five minutes (middle), and ten minutes (right) for the grid of $0.1^{\circ} \mathrm{X}$ $0.1^{\circ}$. 
Salma et al: Estimation of Raindrop Size Distribution Parameters Based on Lightning Data

Table 1 Linear fit equation between the number of lightning strokes, rainfall rate, and DSD parameters in for the grid of $0.1^{\circ} \times 0.1^{\circ}$.

\begin{tabular}{|c|c|c|c|c|}
\hline \multirow{2}{*}{ Locations } & \multirow{2}{*}{ Parameters } & \multicolumn{3}{|c|}{ Average time } \\
\hline & & 1-min & $5-\min$ & 10-min \\
\hline \multirow[t]{4}{*}{ Kototabang } & $R$ vs Number of strokes & $\begin{array}{l}y=1.72 x+8.58 \\
R^{2}=0.0\end{array}$ & $\begin{array}{l}y=0.54 x+6.75 \\
R^{2}=0.01\end{array}$ & $\begin{array}{l}y=0.72 x+1.01 \\
R^{2}=0.09\end{array}$ \\
\hline & $\Lambda$ vs Number of strokes & $\begin{array}{l}y=0.48 x+9.89 \\
R^{2}=0.0\end{array}$ & $\begin{array}{l}y=0.70 x+4.78 \\
R^{2}=0.08\end{array}$ & $\begin{array}{l}y=0.26 x+6.25 \\
R^{2}=0.06\end{array}$ \\
\hline & $\mu$ vs Number of strokes & $\begin{array}{l}y=0.41 x+5.42 \\
R^{2}=0.0\end{array}$ & $\begin{array}{l}y=0.42 x+2.54 \\
R^{2}=0.08\end{array}$ & $\begin{array}{l}y=0.18 x+3.00 \\
R^{2}=0.08\end{array}$ \\
\hline & $N_{\mathrm{T}}$ vs Number of strokes & $\begin{array}{l}y=-46.60 x+372.65 \\
R^{2}=0.01\end{array}$ & $\begin{array}{l}y=-4.92 x+327.84 \\
R^{2}=0.0\end{array}$ & $\begin{array}{l}y=-0.43 x+ \\
298.91 ; R^{2}=0.0\end{array}$ \\
\hline \multirow[t]{4}{*}{ Sicincin } & $R$ vs Number of strokes & $\begin{array}{l}y=-0.15 x+19.26 \\
R^{2}=0.0\end{array}$ & $\begin{array}{l}y=1.15 x+12.24 \\
R^{2}=0.0\end{array}$ & $\begin{array}{l}y=1.75 x+1.75 \\
R^{2}=0.03\end{array}$ \\
\hline & $\Lambda$ vs Number of strokes & $\begin{array}{l}y=-3.47 x+13.13 \\
R^{2}=0.03\end{array}$ & $\begin{array}{l}y=0.48 x+6.14 \\
R^{2}=0.01\end{array}$ & $\begin{array}{l}y=-0.50 x+14.94 ; \\
R^{2}=0.04\end{array}$ \\
\hline & $\mu$ vs Number of strokes & $\begin{array}{l}y=-2.01 x+8.81 \\
R^{2}=0.02\end{array}$ & $\begin{array}{l}y=-0.09 x+6.94 \\
R^{2}=0.0\end{array}$ & $\begin{array}{l}y=-0.26 x+9.54 \\
R^{2}=0.02\end{array}$ \\
\hline & $N_{\mathrm{T}}$ vs Number of strokes & $\begin{array}{l}y=61.43 x+6.21 .75 \\
R^{2}=0.0\end{array}$ & $\begin{array}{l}y=26.27 x+538.57 \\
R^{2}=0.0\end{array}$ & $\begin{array}{l}y=68.31 x+ \\
118.01 ; R^{2}=0.09\end{array}$ \\
\hline
\end{tabular}

To increase the number of lightning strokes observed for each rain, we calculated the number of lightning for the $0.5^{\circ} \times 0.5^{\circ}$ and $1^{\circ} \times 1^{\circ}$ grids. Tables 2 and 3 show the linear fit equations between lightning and DSD parameters. From these two tables, it can be seen that increasing the grid size, thereby increasing the number of lightning strokes, does not increase the value of the determinant coefficient.

Table 2 Linear fit equation between the number of lightning strokes, rainfall rate, and DSD parameters in for the grid of $0.5^{\circ} \times 0.5^{\circ}$.

\begin{tabular}{|c|c|c|c|c|}
\hline \multirow{2}{*}{ Locations } & \multirow{2}{*}{ Parameters } & \multicolumn{3}{|c|}{ Average time } \\
\hline & & 1-min & 5-min & 10-min \\
\hline \multirow[t]{4}{*}{ Kototabang } & $R$ vs Number of strokes & $\begin{array}{l}y=0.46 x+8.89 \\
R^{2}=0.0\end{array}$ & $\begin{array}{l}y=-0.62 x+10.41 \\
R^{2}=0.0\end{array}$ & $\begin{array}{l}y=-0.71 x+10.56 \\
R^{2}=0.0\end{array}$ \\
\hline & $\Lambda$ vs Number of strokes & $\begin{array}{l}y=-0.17 x+11.53 \\
R^{2}=0.0\end{array}$ & $\begin{array}{l}y=-0.49 x+11.95 \\
R^{2}=0.0\end{array}$ & $\begin{array}{l}y=-0.23 x+11.61 \\
R^{2}=0.0\end{array}$ \\
\hline & $\mu$ vs Number of strokes & $\begin{array}{l}y=-0.09 x+6.47 \\
R^{2}=0.0\end{array}$ & $\begin{array}{l}y=-0.16 x+6.57 \\
R^{2}=0.0\end{array}$ & $\begin{array}{l}y=-0.07 x+6.45 \\
R^{2}=0.0\end{array}$ \\
\hline & $N_{\mathrm{T}}$ vs Number of strokes & $\begin{array}{l}y=11.80 x+246.05 \\
R^{2}=0.0\end{array}$ & $\begin{array}{l}y=10.36 x+248.96 \\
R^{2}=0.0\end{array}$ & $\begin{array}{l}y=9.43 x+249.74 \\
R^{2}=0.0\end{array}$ \\
\hline \multirow[t]{4}{*}{ Padang } & $R$ vs Number of strokes & $\begin{array}{l}y=-0.34 x+8.25 \\
R^{2}=0.0\end{array}$ & $\begin{array}{l}y=-0.35 x+10.80 \\
R^{2}=0.01\end{array}$ & $\begin{array}{l}y=-0.19 x+11.16 \\
R^{2}=0.02\end{array}$ \\
\hline & $\Lambda$ vs Number of strokes & $\begin{array}{l}y=1.20 x+10.04 \\
R^{2}=0.03\end{array}$ & $\begin{array}{l}y=0.45 x+8.11 \\
R^{2}=0.08\end{array}$ & $\begin{array}{l}y=0.16 x+9.34 \\
R^{2}=0.06\end{array}$ \\
\hline & $\mu$ vs Number of strokes & $\begin{array}{l}y=0.64 x+7.56 \\
R^{2}=0.02\end{array}$ & $\begin{array}{l}y=0.25 x+6.42 \\
R^{2}=0.08\end{array}$ & $\begin{array}{l}y=0.11 x+6.75 \\
R^{2}=0.07\end{array}$ \\
\hline & $N_{\mathrm{T}}$ vs Number of strokes & $\begin{array}{l}y=-4.45 x+456.99 \\
R^{2}=0.0\end{array}$ & $\begin{array}{l}y=-3.62 x+482.10 \\
R^{2}=0.0\end{array}$ & $\begin{array}{l}y=-2.09 x+ \\
487.33 ; R^{2}=0.0\end{array}$ \\
\hline \multirow[t]{4}{*}{ Sicincin } & $R$ vs Number of strokes & $\begin{array}{l}y=1.71 x+10.98 \\
R^{2}=0.01\end{array}$ & $\begin{array}{l}y=0.77 x+6.99 \\
R^{2}=0.03\end{array}$ & $\begin{array}{l}y=0.43 x+6.10 \\
R^{2}=0.04\end{array}$ \\
\hline & $\Lambda$ vs Number of strokes & $\begin{array}{l}y=-0.43 x+12.00 \\
R^{2}=0.0\end{array}$ & $\begin{array}{l}y=-0.23 x+13.31 ; \\
R^{2}=0.02\end{array}$ & $\begin{array}{l}y=-0.12 x+13.38 \\
R^{2}=0.02\end{array}$ \\
\hline & $\mu$ vs Number of strokes & $\begin{array}{l}y=-0.21 x+7.99 \\
R^{2}=0.0\end{array}$ & $\begin{array}{l}y=-0.12 x+8.71 \\
R^{2}=0.01\end{array}$ & $\begin{array}{l}y=-0.07 x+8.81 \\
R^{2}=0.02\end{array}$ \\
\hline & $N_{\mathrm{T}}$ vs Number of strokes & $\begin{array}{l}y=38.30 x+525.17 \\
R^{2}=0.01\end{array}$ & $\begin{array}{l}y=18.43 x+424.97 \\
R^{2}=0.02\end{array}$ & $\begin{array}{l}y=10.50 x+ \\
401.04 ; R^{2}=0.03\end{array}$ \\
\hline
\end{tabular}


Table 3 Linear fit equation between the number of lightning strokes, rainfall rate, and DSD parameters in for the grid of $1.0^{\circ} \times 1.0^{\circ}$.

\begin{tabular}{|c|c|c|c|c|}
\hline \multirow[b]{2}{*}{ Locations } & \multirow[b]{2}{*}{ Parameters } & \multicolumn{3}{|c|}{ Average time } \\
\hline & & 1-min & 5-min & 10-min \\
\hline \multirow[t]{4}{*}{ Kototabang } & $R$ vs Number of strokes & $\begin{array}{l}y=-0.05 x+7.08 \\
R^{2}=0.0\end{array}$ & $\begin{array}{l}y=-0.01 x+7.09 \\
R^{2}=0.0\end{array}$ & $\begin{array}{l}y=0.01 x+6.70 \\
R^{2}=0.0\end{array}$ \\
\hline & $\Lambda$ vs Number of strokes & $\begin{array}{l}y=0.14 x+11.46 \\
R^{2}=0.0\end{array}$ & $\begin{array}{l}y=0.07 x+11.11 \\
R^{2}=0.0\end{array}$ & $\begin{array}{l}y=0.04 x+10.96 \\
R^{2}=0.0\end{array}$ \\
\hline & $\mu$ vs Number of strokes & $\begin{array}{l}y=0.02 x+6.48 \\
R^{2}=0.0\end{array}$ & $\begin{array}{l}y=0.01 x+6.43 \\
R^{2}=0.0\end{array}$ & $\begin{array}{l}y=0.00 x+6.50 \\
R^{2}=0.0\end{array}$ \\
\hline & $N_{\mathrm{T}}$ vs Number of strokes & $\begin{array}{l}y=0.55 x+249.49 \\
R^{2}=0.0\end{array}$ & $\begin{array}{l}y=0.01 x+6.43 \\
R^{2}=0.0\end{array}$ & $\begin{array}{l}y=0.57 x+239.86 \\
R^{2}=0.0\end{array}$ \\
\hline \multirow[t]{4}{*}{ Padang } & $R$ vs Number of strokes & $\begin{array}{l}y=-0.31 x+6.59 \\
R^{2}=0.0\end{array}$ & $\begin{array}{l}y=-0.09 x+6.88 \\
R^{2}=0.0\end{array}$ & $\begin{array}{l}y=-0.10 x+7.90 \\
R^{2}=0.01\end{array}$ \\
\hline & $\Lambda$ vs Number of strokes & $\begin{array}{l}y=1.00 x+9.82 \\
R^{2}=0.03\end{array}$ & $\begin{array}{l}y=0.34 x+8.46 \\
R^{2}=0.06\end{array}$ & $\begin{array}{l}y=0.16 x+8.64 \\
R^{2}=0.08\end{array}$ \\
\hline & $\mu$ vs Number of strokes & $\begin{array}{l}y=0.55 x+7.38 \\
R^{2}=0.02\end{array}$ & $\begin{array}{l}y=0.19 x+6.57 \\
R^{2}=0.05\end{array}$ & $\begin{array}{l}y=0.10 x+6.49 \\
R^{2}=0.08\end{array}$ \\
\hline & $N_{\mathrm{T}}$ vs Number of strokes & $\begin{array}{l}y=1.43 x+368.75 \\
R^{2}=0.0\end{array}$ & $\begin{array}{l}y=0.82 x+363.55 \\
R^{2}=0.0\end{array}$ & $\begin{array}{l}y=-1.08 x+392.78 ; \\
R^{2}=0.0\end{array}$ \\
\hline \multirow[t]{4}{*}{ Sicincin } & $R$ vs Number of strokes & $\begin{array}{l}y=0.05 x+9.71 \\
R^{2}=0.0\end{array}$ & $\begin{array}{l}y=0.02 x+9.61 \\
R^{2}=0.0\end{array}$ & $\begin{array}{l}y=-0.01 x+9.97 \\
R^{2}=0.0\end{array}$ \\
\hline & $\Lambda$ vs Number of strokes & $\begin{array}{l}y=0.07 x+12.40 \\
R^{2}=0.0\end{array}$ & $\begin{array}{l}y=0.03 x+12.31 \\
R^{2}=0.0\end{array}$ & $\begin{array}{l}y=0.03 x+12.06 \\
R^{2}=0.0\end{array}$ \\
\hline & $\mu$ vs Number of strokes & $\begin{array}{l}y=0.01 x+8.30 \\
R^{2}=0.0\end{array}$ & $\begin{array}{l}y=0.00 x+8.28 \\
R^{2}=0.0\end{array}$ & $\begin{array}{l}y=0.00 x+8.23 \\
R^{2}=0.0\end{array}$ \\
\hline & $N_{\mathrm{T}}$ vs Number of strokes & $\begin{array}{l}y=3.23 x+464.22 \\
R^{2}=0.0\end{array}$ & $\begin{array}{l}y=1.45 x+455.35 \\
R^{2}=0.0\end{array}$ & $\begin{array}{l}y=0.55 x+459.27 \\
R^{2}=0.0\end{array}$ \\
\hline
\end{tabular}

From the discussion above, it can be seen that the relationship between lightning and DSD parameters is very weak. The correlation is much smaller than that obtained by previous researchers (Saylor et al., 2005; Lapp, 2007). The low correlation is probably due to the small-time average and the regression method used. Figure 4 shows the time series $R$ and DSD parameters in Kototabang along with lightning in a $0.1^{\circ}$ grid. The time interval is one minute. It can be seen that the peak of rainfall rate and the peak of lightning are not the same. Not every minute of rain is followed by lightning. Therefore, the use of a short time interval cannot provide a strong relationship between lightning and DSD parameters (Figure 3). Saylor et al. (2005) analyzed the relationship of lightning and DSD parameters with longer time intervals: hourly and daily, and got a better correlation coefficient. However, Lapp (2007) who also uses a time interval of 1 hour gets a weak correlation $(r<0.5)$. The second possible factor is the use of linear regression. Saylor et al. (2005) uses power law fit, and Lapp (2007) uses exponential fit and gets a stronger correlation. Saylor et al. (2005) also examined the use of linear fit and also shows a very weak relationship. However, the use of the two fits, as used by previous researchers, did not significantly increase the correlation coefficient in this study (figure not shown). Thus, the time interval is probably the main factor. Thus, it can be concluded that using lightning data to calculate DSD parameters is possible for long time intervals ( $>1$ hour) and not possible for short time intervals.

\section{CONCLUSION}

This study shows that the relationship between the number of lightning strokes, the rain rate, and DSD parameters in West Sumatra for short time intervals $(<10 \mathrm{~min})$ is very weak because not every minute of rain is followed by lightning. Thus, using lightning data to calculate DSD parameters is possible for long time intervals (> 1 hour), as previously tested by several previous researchers. The 
current research is still limited to three locations; currently, we are developing a method to estimate DSD from lightning data using DSD parameters from spaceborne radar for hourly and daily intervals.
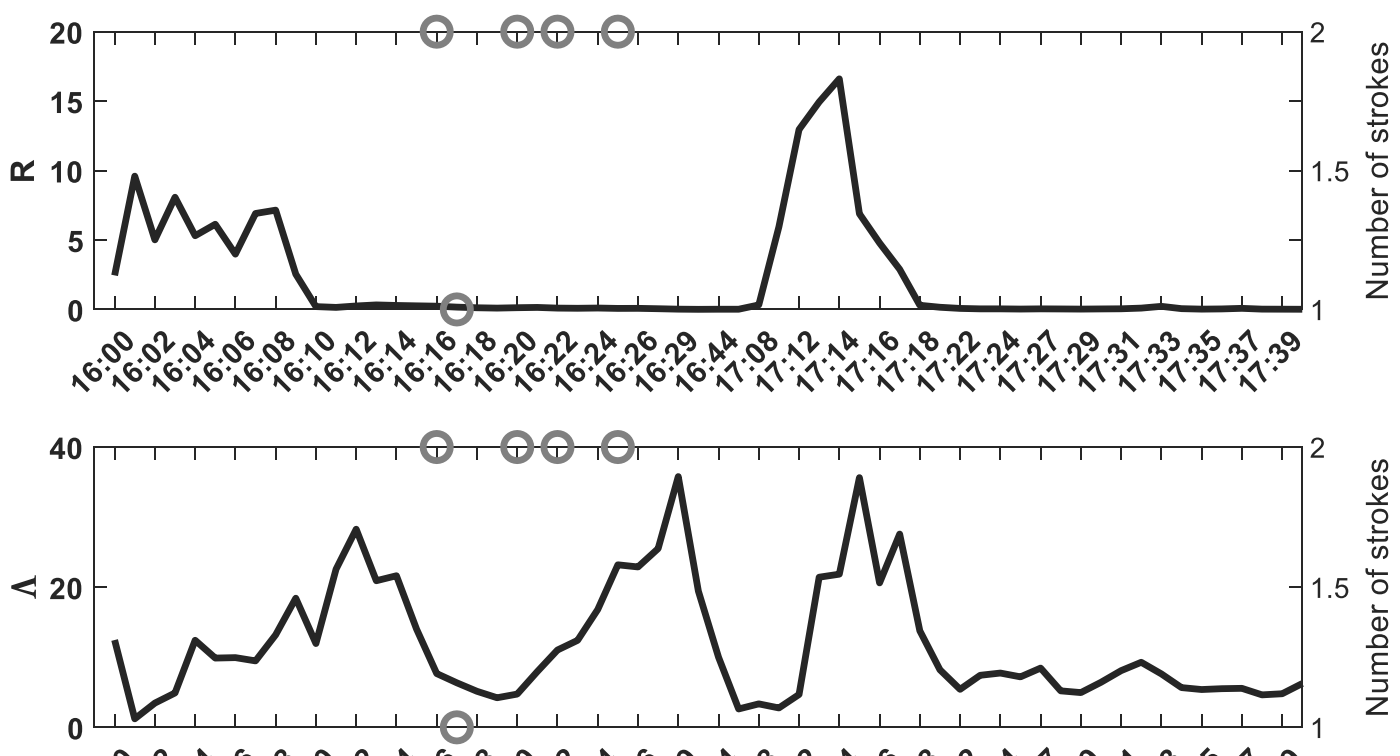

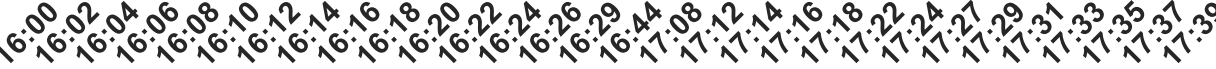

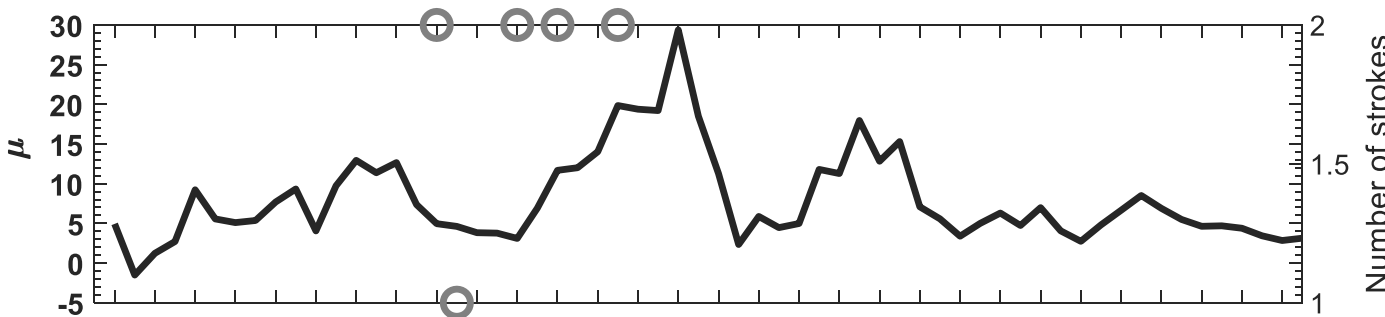

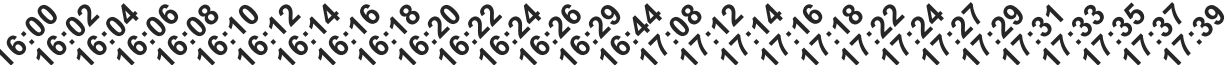

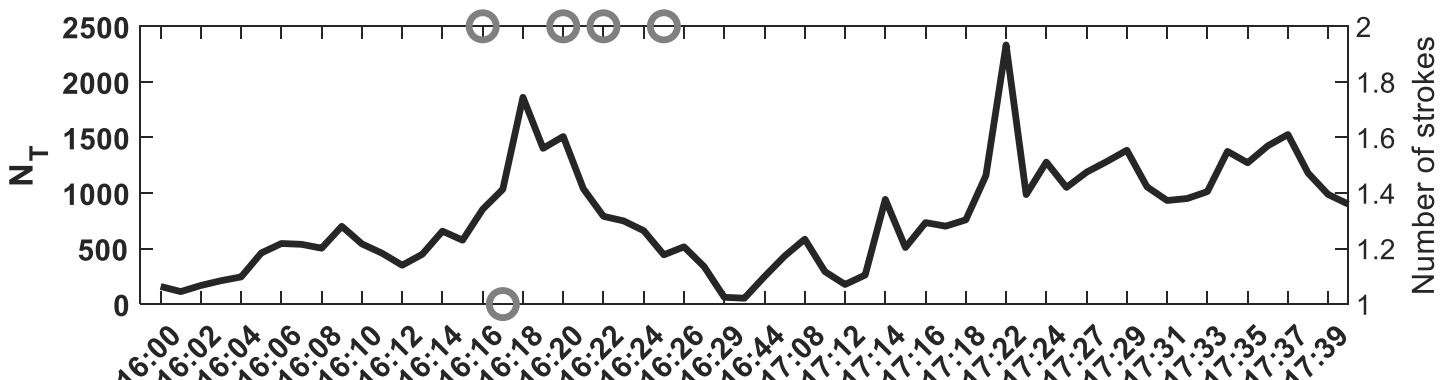

Time (Local Time)

Figure 4 Time series of the relationship between $R, \Lambda, \mu$ and $N_{\mathrm{T}}$ with the number of lightning strokes on 14 March 2017 during 16:00 - 17:39 local time at Kototabang for a grid of $0.1^{\circ} \times 0.1^{\circ}$.

\section{ACKNOWLEDGEMENT}

Observations of Parsivel were supported by the Research Institute for Sustainable Humanosphere (RISH), Kyoto University. We would like to thank Mr.Sugeng Nugroho from the Indonesian Agency for Meteorological, Climatological, and Geophysics, Indonesia, for operating Parsivel in Sicincin. 


\section{REFERENCE}

Albrecht, R.I., Goodman, S.J., Buechler, D.E., Blakeslee, R.J. \& Christian, H.J. (2015). Where are the lightning hotspots on Earth, Bulletin of the American Meteorological Society, 97(11), 2051-2068.

Atlas, D., Ulbrich, C.W., Marks, F.D., Amitai, E. \& Williams, C.R (1999). Systematic Variation of Drop Size and Radar-Rainfall Relationships, Journal of Geophysical Research, 104, 6155-6169.

Avila, M.C, Nora A, Cornelli E, Rodriguez-Castellon A \& Jimenez-Lopez, (2010). Study of solid acid catalysis for the hydration of $\alpha$-pinene. Journal of Molecular Catalysis A: Chemical, 322, 106-122.

Bourscheidt, V., Pinto, O., Naccarato, K. P., \& Pinto, I. R. C. A. (2009). The influence of topography on the cloudto-ground lightning density in South Brazil. Atmospheric Research, 91(2-4), 508-513. doi:10.1016/j.atmosres.2008.06.010.

Coppens, D. \& Haddad, Z.S. (2000), Effect of Raindrop Size Distribution Variation on Microwave Brightness Temperature Calculation, Journal of Geophysical Research, 105 (19), 483-489.

Harikumar, R., Sampath, S., Kumar, V.S. (2009), An empirical model for the variation of rain drop size distribution with rain rate at a few locations in southern India. Advances in Space Research, 43, 837-844.

Harjupa, W., Shimomai, T., Hashiguchi, H., Fujiyoshi, Y., \& Kawashima, M. (2021). Differences in Mechanisms of Orographic Rainfall over West Sumatra (Case Study: 10 April and 23 April 2004). Jurnal Ilmu Fisika, 13(1), 8-17. doi:https://doi.org/10.25077/jif.13.1.8-17.2021

Jameson, A.R. \& Kostinski, A.B. (2001), What is Raindrop Size Distribution, Bulletin of American Meteorological Society, 82 (6), 1169-1177.

Kozu, T. \& Nakamura, K. (1991), Rainfall Parameter Estimation from Dual-Radar Measurements Combining Reflectivity Profile and Path-integrated Attenuation, Journal of Atmospheric and Oceanic Technology, 8, 259-271.

Lapp, J., (2007), Analyzing Relationships Between Lightning and Rain in Order to Improve Estimation Accuracy of Rain, Theses, Clemson University, USA.

Loffler-Mang, M. \& Joss, J. (2000), An Optical Disdrometer for Measuring Size and Velocity of Hydrometeors, Journal of Atmospheric and Oceanic Technology, 17, 130-139.

Marzuki, Kozu, T., Shimomai, T, Hashiguchi, H., Randeu, W.L., \& Vonnisa, M., (2010), Raindrop Size Distribution of Convective Rain Over Equatorial Indonesia During the firs CPEA Campaign, Atmospheric Research, 96, 645-655.

Marzuki, M., Hashiguchi, H., Yamamoto, M.K., Mori, S., \& Yamanaka, M.D., (2013a), Regional Variability of Raindrop Size Distribution over Indonesia, Annales Geophysical, 31, 1941-1948.

Marzuki, Hashiguchi, H., Yamamoto, M.K., Yamamoto. M., Mori. S., Yamanaka, M. D, Carbone, R. E, \& Tuttle, J. D. (2013b) Cloud episode propagation over the Indonesian maritime continent from 10 years of infrared brightness temperature observations. Atmospheric Research, 120-121, 268-286. https://doi.org/10.1016/j.atmosres.2012.09.004

Marzuki, Hashiguchi, H.,Shimomai, T., \& Randeu, Walter L. (2016), Cumulative Distributions of Rainfall Rate Over Sumatra, Progress In Electromagnetics Research M, 49, 1-8, doi:10.2528/PIERM16043007.

Marzuki, M, Suryanti, K, Yusnaini, H, et al. (2021). Diurnal variation of precipitation from the perspectives of precipitation amount, intensity and duration over Sumatra from rain gauge observations. International Journal of Climatology. 1-12. https://doi.org/10.1002/joc.7078

Owolawi, P. (2011), Raindrop Size Distribution Model for the prediction of Rain Attenuation in Durban, PIERS Online, 7 (6), 516-523.

Saufina, E., Marzuki, M., Vonnisa, M., Hashiguchi, H., \& Harmadi, H., (2018), Seasonal and Diurnal Variations of Lightning Activity Over West Sumatra and Its Correlation with Precipitation Type, Makara Journal of Science, 22 (2), 95-104, DOI: 10.7454/mss.v22i2.8089.

Saylor, J.R., Ulbrich, C.W., Ballentine, J.W \& Lapp J.L., (2005), The Correlation Between Lightning and DSD Parameters, IEEE Transactions on Geoscience and Remote Sensing, 43 (8), 1806 - 1815.

Tokay, A. \& Short, D.A., (1996), Evidence from Tropical Raindrop Spectra of the Origin of Rain from Statifrom Versus Convective Clouds, Journal Applied Meteorology, 35, 355-371.

Uijlenhoet, R., (2010), Raindrop Size Distributions and Radar Reflectivity-Rain Rate Relationships for Radar Hydrology, Hydrology and Earth System Sciences, 5, 615-627.

Waldvogel, A., (1974), The $\mathrm{N}_{0}$ Jump of Raindrop Spectra, Journal of Atmospheric Society, 31, 1067-1078.

Yusnaini, Marzuki, Muharsyah, R., Vonnisa, M., \& Tangang, F., (2021) Influence of topography on lightning density in Sumatra, Journal of Physics: Conference Series. 1876012022. 